\title{
Arterial switch operation: progress in approaching a zero mortality rate
}

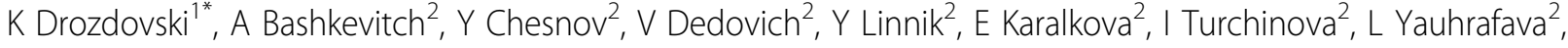 \\ W Novick ${ }^{3}$
}

From 23rd World Congress of the World Society of Cardio-Thoracic Surgeons

Split, Croatia. 12-15 September 2013

\section{Background}

The learning curve for the arterial switch operation (ASO) has been reported to be steep. We reviewed our entire experience in the ASO from 1996 to determine the change in mortality over time and determine what factors, if any, resulted in our current annual mortality of $0 \%$.

\section{Methods}

The database of our institution was reviewed for all children undergoing the arterial switch procedure. All ASO's were included; ASO/IVS, ASO/VSD, ASO/arch repair, $\mathrm{ASO} / \mathrm{VSD} /$ arch repair. Multivariate analysis of those factors which might have an influence on mortality was performed.

\section{Results}

A total of 163 ASO procedures of all types were identified. The diagnoses were; TGA/IVA 88, TGA/VSD 53, TGA/ arch 5, TGA/VSD/arch 4, Taussig Bing 10, Taussig Bing/ arch 9, for a total of 169, ten patients underwent a staged repair in preparation for ASO of which 4 died. One died before intervention, one did not undergo ASO operation at our institution. Total mortality for all ASO procedures was $23 \%$ (38/163). Mortality over time decreased from $100 \%$ in 1996 to $0 \%$ in 54 consecutive patients between June 2009 and December 2012. A linear relationship in mortality was noted over time, with a correlation coefficient of 0.88. Analysis of other factors including; coronary anatomy, type of ASO, cross-clamp time did not reveal significant differences. The ASO/VSD operation was initially a risk factor with an overall mortality of $28 \%(15 / 53)$, however this disappeared over time.

* Correspondence: kdrozdovski@mail.ru

'Pediatric Surgery, National Children's Cardiac Surgical Center, Minsk, Belarus Full list of author information is available at the end of the article

\section{Conclusion}

A significant learning curve is required to achieve low mortality in the ASO. Early failure should not discourage pursuit of improved results.

\section{Authors' details}

'Pediatric Surgery, National Children's Cardiac Surgical Center, Minsk, Belarus. ${ }^{2}$ Pediatric Cardiac Surgery, National Children's Cardiac Surgical Center, Minsk, Belarus. ${ }^{3}$ Department of Surgery, University of Tennessee Health Sciences Center and International Children's Heart Foundation, Memphis, TN, USA.

Published: 11 September 2013

doi:10.1186/1749-8090-8-S1-0307

Cite this article as: Drozdovski et al: Arterial switch operation: progress in approaching a zero mortality rate. Journal of Cardiothoracic Surgery 2013 8(Suppl 1):0307.

Submit your next manuscript to BioMed Central and take full advantage of:

- Convenient online submission

- Thorough peer review

- No space constraints or color figure charges

- Immediate publication on acceptance

- Inclusion in PubMed, CAS, Scopus and Google Scholar

- Research which is freely available for redistribution

Submit your manuscript at www.biomedcentral.com/submit

\section{() Biomed Central}

\section{() Biomed Central}

